\title{
Hydroclimatic changes and drivers in the Sava River Catchment and comparison with Swedish catchments
}

\author{
Lea Levi, Fernando Jaramillo, Roko Andričević, \\ Georgia Destouni
}

Received: 7 May 2014/Revised: 25 August 2014/ Accepted: 11 February 2015/Published online: 10 March 2015

\begin{abstract}
In this study, we investigate long-term hydroclimatic changes and their possible relation to regional changes in climate, land-use and water-use over the twentieth century in the transboundary Sava River Catchment (SRC) in South Eastern Europe. In a hydropower dominated part of the SRC, unlike in an unregulated part, we find increase in average annual evapotranspiration and decrease in temporal runoff variability, which are not readily explainable by observed concurrent climate change in temperature and precipitation and may be more related to landscape-internal change drivers. Among the latter investigated here, results indicate hydropower developments as most closely related to the found hydroclimatic shifts, consistent with previous such indications in studies of Swedish hydropower catchments. Overall, the present results have quantitatively framed the recent history and present state of hydroclimate in the SRC, of relevance for water resources in several countries and for a majority of their populations. This provides a useful basis for further assessment of possible future hydroclimatic changes, under different scenarios of climate change and land/water-use developments in the region.
\end{abstract}

Keywords Hydroclimatic change - Evapotranspiration . Runoff variability · Land-use · Hydropower · Sava River

\section{INTRODUCTION}

Growing concerns about and needs to plan for availability, quality, and sustainable use of freshwater require good understanding of past and present conditions, detection of

Electronic supplementary material The online version of this article (doi:10.1007/s13280-015-0641-0) contains supplementary material, which is available to authorized users. changes and identification of the causes and possible longterm consequences of changing water resources. Water conditions in the world's land areas interact constantly with natural and anthropogenic climate change (Hamlet and Lettenmaier 1999; Christensen et al. 2004; Nilsson et al. 2005; Seneviratne et al. 2006; Poff et al. 2007; Dyurgerov et al. 2010, Botter et al. 2013). In addition, the conditions of water on land are also affected by direct anthropogenic changes in land-use (e.g., expansion and/or intensification of agriculture, irrigation expansion, deforestation) and water-use (e.g., water diversions for irrigation, decrease in surface water area due to water diversions, water system modifications related to hydropower expansion) in the landscape itself (Gordon et al. 2005; Botter et al. 2010; Naik and Jay 2011; Destouni et al. 2013; Montanari et al. 2013; Jaramillo and Destouni 2014).

Impacts of climate change on water resources and their management have been recognized and studied for some time (Milly et al. 2005; Darracq et al. 2005; Groves et al. 2008; Kundzewicz et al. 2008; Wisser et al. 2010; Jarsjö et al. 2012). Studies of the water resource effects of changes in human land/water-use have shown that these may be as large as the climate-driven effects, for instance, on evapotranspiration and runoff fluxes (Shibuo et al. 2007; Cuo et al. 2009; Asokan et al. 2010; Kvalevåg et al. 2010; Niyogi et al. 2010; Jarsjö et al. 2012; Sorooshian et al. 2012; Destouni et al. 2013). For example, major water diversions for new irrigation schemes in the Aral Sea drainage basin have increased water losses to the atmosphere by increasing evapotranspiration from irrigated agricultural areas, thereby decreasing runoff to the Aral Sea and causing its dramatic shrinkage from the mid twentieth century until present time (Shibuo et al. 2007; Destouni et al. 2010). These historic land- and water-use changes will also continue to condition future freshwater responses 
to forthcoming climate change in the region (Jarsjö et al. 2012). Furthermore, Degu et al. (2011) have shown that large dams in various parts of the United States affect available potential energy, surface evaporation, and specific humidity in the atmosphere over distances of up to $100 \mathrm{~km}$ from the water reservoirs. Several other recent studies have also reported direct impacts of such anthropogenic changes in land-use and water-use on regional climate (Lobell et al. 2009; Asokan et al. 2010, Destouni et al. 2010; Hossain 2010; Lee et al. 2011; Degu et al. 2011; Asokan and Destouni 2014). In order to improve our predictive capability for future hydroclimatic changes, there is a need to increase understanding of water changes and their main drivers by further studies of such change manifestations under climatic and land/water-use conditions prevailing in different world regions.

In this study, we investigate the hydroclimatic change manifestations and their possible drivers in the major transboundary Sava River Catchment (SRC; Fig. 1), draining into the Danube River in South-Eastern Europe. The SRC represents a world region with relatively limited open accessibility to environmental data, spanning across countries that have undergone recent political and social instability, which also influences the data accessibility situation. For this region, we here use a wide range of sources to compile times series of hydroclimatic data, as well as data on land-use and water-use developments in the catchment over a large part of the twentieth century.

A main aim of this data compilation is to investigate the past-to-present hydroclimatic changes observed in the SRC. A second study aim is to relate the observed water changes in the landscape to various possible change drivers, including atmospheric climate change and historic land/water-use developments in the region; with regard to the latter, watercourses in the SRC have in particular been subject to major regulation for hydropower production and flood protection since the 1950s, indicating the SRC as a possibly useful candidate site for detecting water change effects of these types of developments, in addition to such effects driven by climate change. A third aim is finally to assess the generality of water change results in the SRC, compared to corresponding results in another, climatically different part of the world with similar land/water-use developments.

\section{MATERIALS AND METHODS}

The SRC (Fig. 1) was delineated based on a Digital Elevation Model (DEM) with resolution of 3 arc-second,

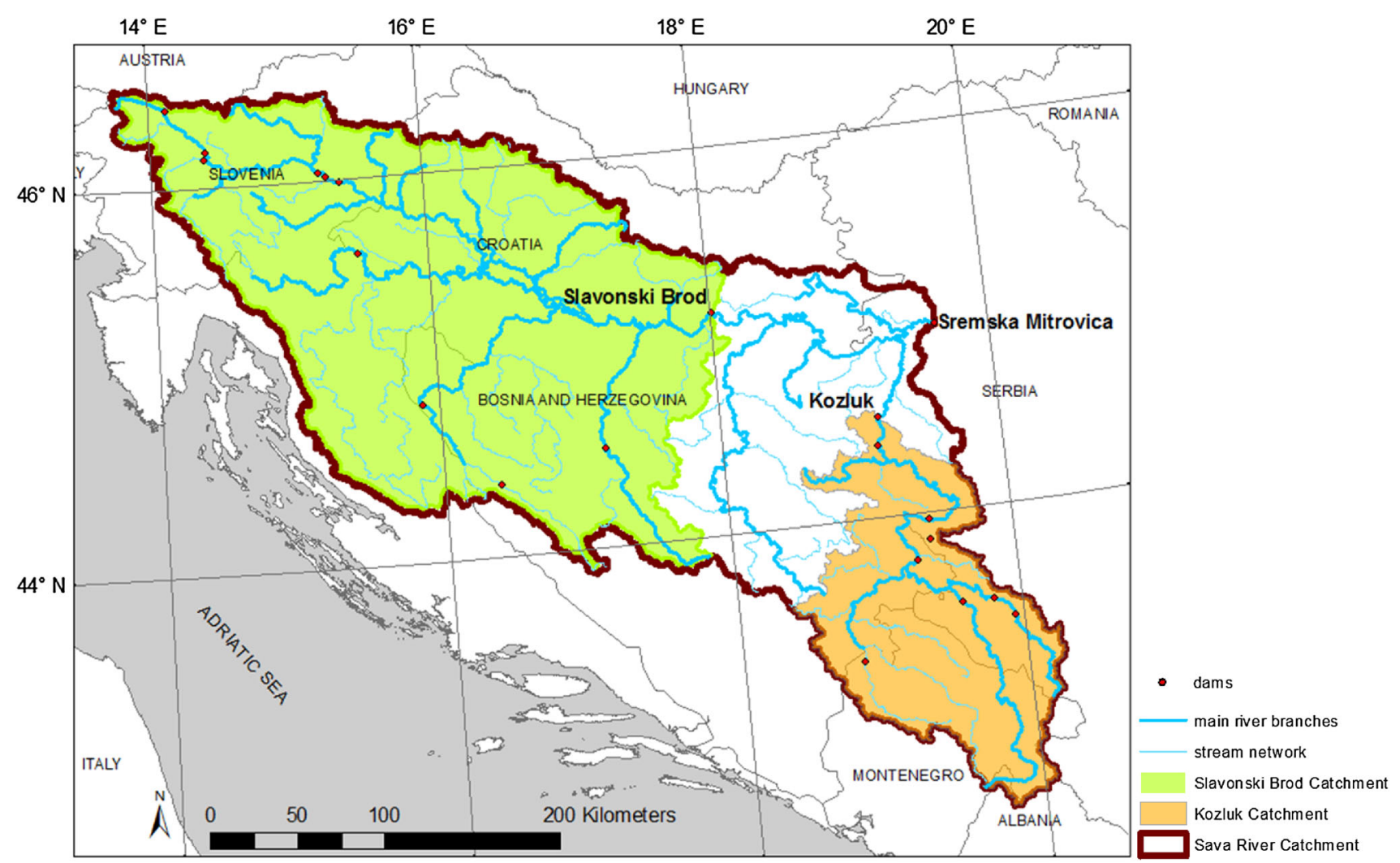

Fig. 1 The Sava River Catchment (as defined by the Sremska Mitrovica discharge station) and two investigated subcatchments (Slavonski Brod and Kozluk) within it 
obtained from the United States Geological Survey (USGS Hydrosheds, US Department of Interior; US Geological Survey 2006) and river network information from the Catchment Characterization and Modelling (CCM) River and Catchment Database (European Commission, Institute for Environment and Ecology 2008). The discharge measurement station that defines the SRC is located at Sremska Mitrovica, located just upstream of Belgrade, with a catchment area of $92158 \mathrm{~km}^{2}$; the Sremska Mitrovica station integrates close to the total SRC discharge into the Danube River, with the total SRC area being $100095 \mathrm{~km}^{2}$ at its outlet into the Danube River.

The SRC extends across six different countries in SouthEastern Europe: Slovenia, Croatia, Bosnia and Herzegovina, Serbia, Monte Negro, and Albania (Fig. 1; the figure shows the SRC part defined by the discharge measurement station Sremska Mitrovica). The Sava River is $990 \mathrm{~km}$ long, with its headwaters in Slovenia and its outlet into the Danube River in Belgrade, Serbia. Sava River is the largest tributary by discharge and the SRC is the second largest catchment by area of the Danube River (International Commission for the Protection of the Danube River (ICPDR) 2005).

The SRC population is about 8176000 people, representing $46 \%$ of the total population in the main SRC countries (excluding the small SRC parts in Albania and Monte Negro; International Sava River Commission 2008). The SRC elevation ranges from sea level up to 2646 meters. Three different climate types prevail in different parts of the catchment: alpine climate, moderate continental climate, and moderate continental (mid-European) climate.

Temperature and precipitation data for the SRC were downloaded from the Climatic Research Unit Database CGIAR-CSI CRU TS 2.1 (Mitchell and Jones 2005), as time series of monthly $T$ and $P$ for the period 1901-2002, at $0.5^{\circ}$ resolution of the land surface. Based on these datasets, average annual $P$ and $T$ were calculated for all data grid cells in the SRC. Over the twentieth century part with complete availability of hydroclimatic data, and on average over the whole SRC, the long-term mean annual temperature $(T)$ and precipitation $(P)$ are $9{ }^{\circ} \mathrm{C}$ and $1108 \mathrm{~mm}_{\text {year }}{ }^{-1}$, respectively (Climatic Research Unit (CRU) 2006; Mitchell and Jones 2005). Sources and time periods of available monthly river discharge data for the Sremska Mitrovica station, from which corresponding runoff $(\mathrm{R}$; discharge normalized with associated catchment area) was calculated, are listed in Supplementary Table S1. Over the same twentieth century part as for the $T$ and $P$ data, the mean annual $R$ is $531 \mathrm{~mm}$ year $^{-1}$.

In order to investigate land-use changes between time periods with available hydroclimatic data, we used land cover data downloaded from The Oak Ridge National Laboratory Distributed Active Archive Center (ORNL DAAC; Goldewijk 2010). Table S2 (Supplementary
Material) summarizes the land cover conditions for the two time periods with required hydroclimatic data availability: 1931-1960 and 1964-1993. Currently, cultivated land covers $23.2 \%$ of the SRC area, pasture $6.7 \%$, boreal forest $1.5 \%$, mixed forest $31.7 \%$, and deciduous forest $36.1 \%$ (Goldewijk 2010). The SRC area covered by water is $0.8 \%$.

With regard to parallel water-use conditions, the use of water for irrigation in the SRC is less than $0.299 \mathrm{~mm}_{\text {year }}{ }^{-1}$ (or $0.03 \mathrm{~km}^{3}$ year $^{-1}$ ), or $0.6 \%$ of the total water-use in the catchment $\left(48 \mathrm{~mm} \mathrm{year}^{-1}\right.$ ), and only $0.28 \%$ of the total SRC area is systematically irrigated (International Sava River Commission 2008). For investigation of water-use changes for other purposes than irrigation, we used data for the historical development of hydropower (in terms of normal annual production), which Destouni et al. (2013) showed to be a fruitful proxy measure for characterization of water flux changes related to hydropower developments, as well as surface area and volume of man-made reservoirs from different online sources (as listed in Table S3; Table S2 also summarizes average normal annual production for the same time periods as for the land cover data). Regarding this type of water-use, there are currently 22 water reservoirs within the SRC with volumes greater than $5 \times 10^{6} \mathrm{~m}^{3}$, among which 16 are used for hydropower production; the largest of the latter contains a water volume of $880 \times 10^{6} \mathrm{~m}^{3}$.

Historically, hydropower production within the SRC started with the first hydropower plant built in 1898. Since then, 19 large dams (Fig. 1) (i.e., dams with embankment height of more than 15 meters and storage volume exceeding $3 \times 10^{6} \mathrm{~m}^{3}$ ) (International Commission on Large Dams 1997) have been built and several more are planned for the near future. Currently, there are 23 hydropower plants (listed and described in Table S3; located next to the dams shown in Fig. 1, with some plants sharing the same water reservoirs) with total normal annual production of $8 \times 10^{6} \mathrm{MWh}$, along with many small and micro-plants (with power capacity range 1-30 MW, and below $1 \mathrm{~kW}$, respectively) (Voros et al. 1999). Along with these plants, flood protection is also provided by multipurpose water reservoirs and dams, with regulation of watercourses, increase of channel cross sections and building of bypass channels, dikes, and detention and retention reservoirs (International Commission for the Protection of the Danube River (ICPDR) 2009).

In addition to analyzing the direct $T, P$, and $R$ data time series (with average values for the two periods 1931-1960 and 1964-1993 summarized in Table S4), in conjunction with available land-use and water-use data (with average values for the same two periods summarized in Table S4), and in order to distinguish possible climate-driven changes of hydroclimatic conditions in the SRC, actual evapotranspiration (AET) was computed according to two different 
approaches, the results of which were directly compared. This distinction and comparison methodology follows that used in several previous studies of hydroclimatic change (Shibuo et al. 2007; Asokan et al. 2010; Destouni et al. 2010, 2013; Jaramillo et al. 2013; Van der Velde et al. 2013; Asokan and Destouni 2014; Jaramillo and Destouni 2014).

In the first approach, annual $\mathrm{AET}_{\mathrm{wb}}$ was computed based on the catchment-scale water balance:

$\mathrm{AET}_{\mathrm{wb}}=P-R-\Delta S$,

where $\Delta S$ denotes annual change in water storage over the catchment. Based on the findings of consistent long-term behavior of $\mathrm{AET}_{\mathrm{wb}}$ for different assumptions of $\Delta S$ magnitude by Destouni et al. (2013) and Jaramillo et al. (2013), we used the simplest assumption of $\Delta S \approx 0$. Average values of $\mathrm{AET}_{\mathrm{wb}}$ for the two periods 1931-1960 and 1964-1993 are summarized in Table S4.

In the second approach, for direct comparison with $\mathrm{AET}_{\mathrm{wb}}$ obtained from Eq. (1), we computed two additional, purely climate-related AET measures, $\mathrm{AET}_{\text {Tclim }}$ and $\mathrm{AET}_{\text {Bclim }}$, based on Turc (1954) (Eq. (2)) and Budyko (1974) (Eq. (3)), respectively, as

$$
\begin{aligned}
\mathrm{AET}_{\mathrm{T} \text { lim }} & =\frac{P}{\sqrt{0.9+\frac{P^{2}}{P E T^{2}}}}, \\
\mathrm{AET}_{\text {Bclim }} & =P \cdot\left(1-e^{-\frac{\mathrm{PET}}{P}}\right),
\end{aligned}
$$

where PET is potential evapotranspiration, obtained from Langbein (1949) as,

$\mathrm{PET}=325+21 \cdot T+0.9 \cdot T^{2}$,

with mean annual temperature $T$ given in ${ }^{\circ} \mathrm{C}$. For clearer time series comparison of AET variation and change, we also scaled the overall levels of $\mathrm{AET}_{\mathrm{Bclim}}$ and $\mathrm{AET}_{\mathrm{Tclim}}$ by multiplication with the ratio of the average $\mathrm{AET}_{\mathrm{wb}}$ over 1931-1993 and the corresponding average value of $\mathrm{AET}_{\mathrm{Bclim}}$ and $\mathrm{AET}_{\mathrm{Tclim}}$, respectively. Resulting multiplication factors for the SRC were then 1.26 for $\mathrm{AET}_{\mathrm{Bclim}}$ and 1.10 for $\mathrm{AET}_{\mathrm{Tclim}}$. This scaling was done for easier visual comparison of variability and change around mean evapotranspiration because the unscaled $\mathrm{AET}_{\text {Bclim }}$ and $\mathrm{AET}_{\text {Tclim }}$ expressions do not necessarily yield accurate such mean levels across all regions and climates (Destouni et al. 2013; Van der Velde et al. 2014). However, it has been shown that use of a single multiplication factor, calibrating the mean $\mathrm{AET}_{\mathrm{Xclim}}$ level (where the index $\mathrm{X}$ may relate to various methods of estimating AET) to fit a relevant catchment-average level of $\mathrm{AET}_{\mathrm{wb}}$, can accurately capture the AET variability around its overall average level, temporally as well as spatially within a catchment (Jarsjö et al. 2008).
In addition to the changes in mentioned $T, P, R, \mathrm{AET}_{\mathrm{wb}}$, $\mathrm{AET}_{\mathrm{Tclim}}$, and $\mathrm{AET}_{\mathrm{Bclim}}$, we also investigated changes from 1931-1960 to 1964-1993 in relative evapotranspiration $\mathrm{AET}_{\mathrm{wb}} / P$ and in temporal variability of $\mathrm{R}$, in terms of the coefficient of variation of daily $R, \mathrm{CV}(R)$. With the paired two-tailed Student $\mathrm{t}$ test, we tested the significance of resulting changes consistently at 0.05 significance level for all variables. The null hypothesis tested was that of no change in the long-term (30-year) average value from 1931-1960 (period 1) to 1964-1993 (period 2), using period 1 as the reference period. The null hypothesis was expressed as: $\mu_{1}=\mu_{2}=\mu$, where $\mu_{1}$ and $\mu_{2}$ are the average values of each investigated variable in period 1 and period 2 , respectively, and the alternative hypothesis $\mu_{1} \neq \mu_{2}$ expresses that there is significant change from period 1 to period 2 . The hypothesized same average value $\mu$ for the two periods was estimated from the available data for the reference period 1 .

One aim of this study was also to assess the possible generality of SRC results in relation to corresponding results in a climatically different part of the world with similar types of land/water-use changes. To address this aim, we compared key SRC results of $\mathrm{AET}_{\mathrm{wb}} / P$ and $\mathrm{CV}(R)$ changes with corresponding previous results (Destouni et al. 2013) for a set of 9 Swedish catchments, which are all climatically different from the SRC, and instead representative of colder oceanic, humid continental and subarctic climates. Destouni et al. (2013) grouped and analyzed the Swedish basins in three categories according to their major twentieth-century changes in human landand water-use: basins with major expansion/intensification of non-irrigated agriculture, basins with major hydropower developments and basins with essentially unregulated rivers and little agriculture. For these groups of Swedish basins, Destouni et al. (2013) found simultaneous increase of $\mathrm{AET}_{\mathrm{wb}} / P$ and $\mathrm{CV}(R)$ under agricultural expansion/intensification in the agricultural basins, $\mathrm{AET}_{\mathrm{wb}} / P$ increase and $\operatorname{CV}(R)$ decrease under hydropower expansion in the hydropower basins and no sustained shifts but only fluctuations in these variables in the unregulated basins with little agriculture. Based on these findings, observed changes in characterisation variables $\mathrm{AET}_{\mathrm{wb}} / P$ and $\mathrm{CV}(R)$ were here used for direct cross-regional comparison in order to address the generality of results for hydroclimatic changes and their possible drivers.

\section{RESULTS}

Figure $2 \mathrm{a}$ shows the variability and change in annual and running 20-year annual average of $T, P$, and $R$ for most of the twentieth century in the SRC. Whereas $T$ has increased, $P$ and $R$ have decreased. With regard to $\mathrm{AET}_{\mathrm{wb}}$, which for 
(a)
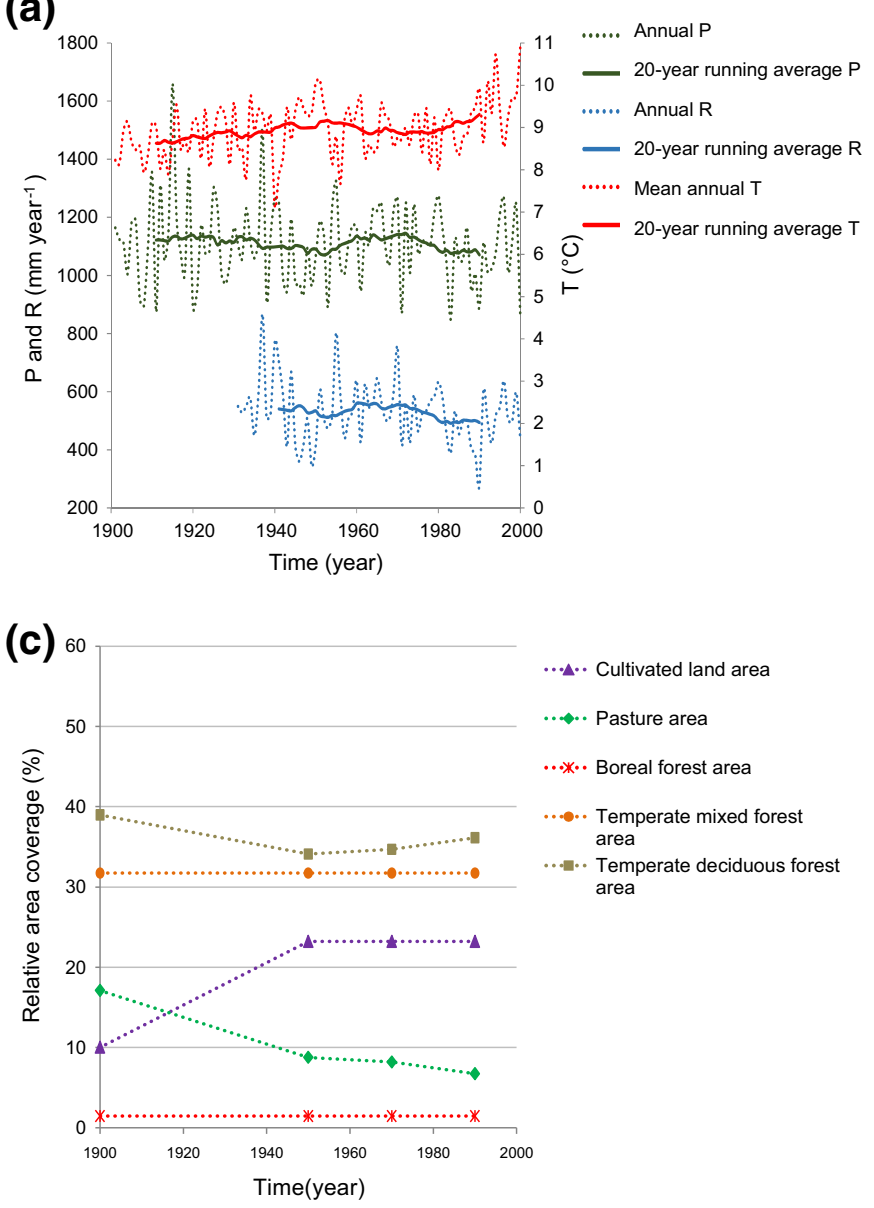

(b)
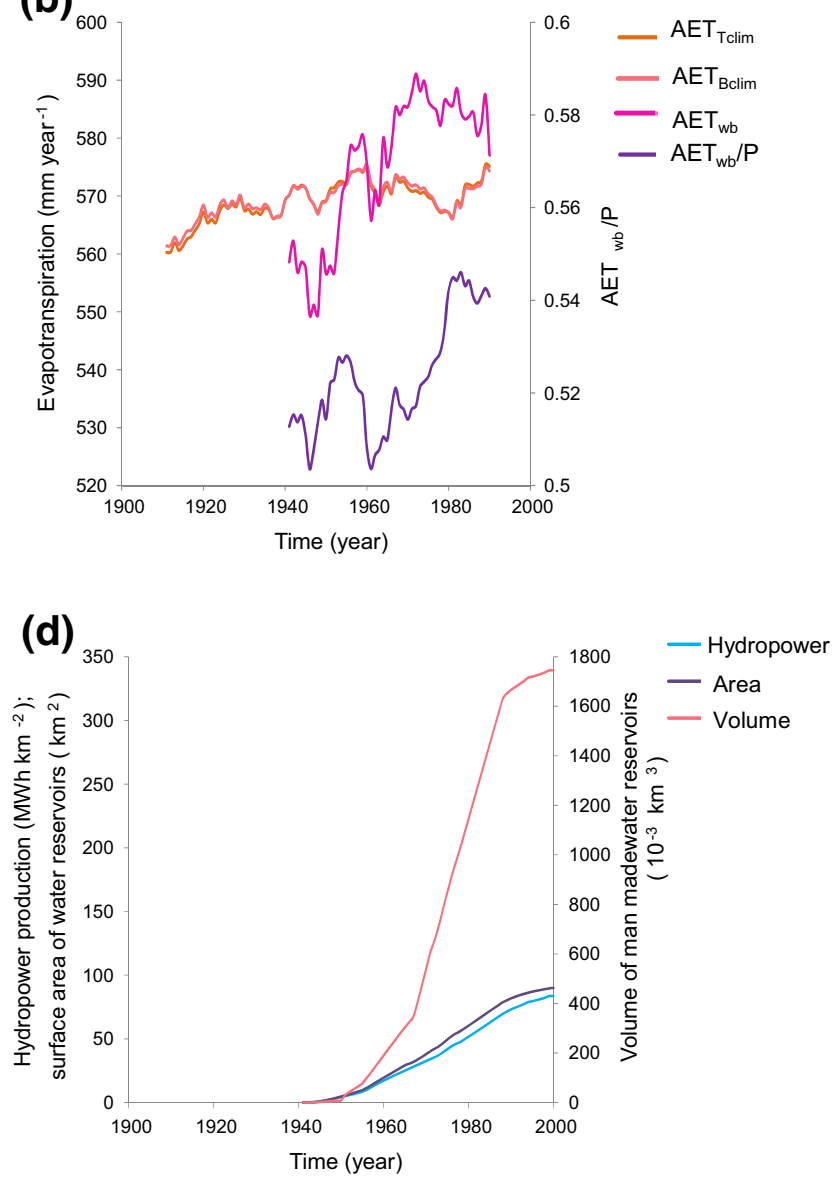

Fig. 2 Change and variable co-development within the Sava River Catchment over the twentieth century. a Temperature $(T)$, precipitation $(P)$ and runoff $(R)$. b Annual average actual evapotranspiration $\left(\mathrm{AET}_{\mathrm{wb}}\right)$ and relative actual evapotranspiration $\left(\mathrm{AET}_{\mathrm{wb}} / P\right)$; results are shown as 20 -year moving averages, with $\mathrm{AET}_{\mathrm{wb}}$ calculated from catchment water balance, and $\mathrm{AET}_{\mathrm{Tclim}}$ and $\mathrm{AET}_{\mathrm{Bclim}}$ calculated from Turc and Budyko Eqs. (2) and (3), respectively; the $\mathrm{AET}_{\mathrm{Tclim}}$ and $\mathrm{AET}_{\mathrm{Bclim}}$ values shown have been scaled by the ratio of average $\mathrm{AET}_{\mathrm{wb}}$ in 1931-1993 and corresponding average $\mathrm{AET}_{\mathrm{Tclim}}$ and $\mathrm{AET}_{\mathrm{Bclim}}$, respectively. $\mathrm{c}$ Total area coverage by different land uses. $\mathbf{d}$ 20-year moving averages of developed annual hydropower production per unit catchment area, water surface area and volume of man-made water reservoirs for the SRC catchment

any given $P$ conditions also affects $R$ (Eq. (1)), Fig. 2b shows the whole $\mathrm{AET}_{\mathrm{wb}}$ time series in comparison with the purely climate-driven $\mathrm{AET}_{\mathrm{Tclim}}$ and $\mathrm{AET}_{\text {Bclim }}$ estimates. A notable increase in $\mathrm{AET}_{\mathrm{wb}}$ can be seen starting sometime around 1950-1960, with $\mathrm{AET}_{\mathrm{wb}}$ thereafter remaining at a higher overall level, even though still fluctuating around that level. No corresponding sustained increase can be seen in the purely climate-related $\mathrm{AET}_{\mathrm{Bclim}}$ and $\mathrm{AET}_{\mathrm{Tclim}}$ estimates, or in the $T$ data (Fig. 2a).

As $P$ also shows an increase during the 1950s (Fig. 2a), an important question is if the absolute $\mathrm{AET}_{\mathrm{wb}}$ shift seen in Fig. $2 \mathrm{~b}$ is temporally reflected in such a shift also in relative $\mathrm{AET}_{\mathrm{wb}} / P$; the latter would imply an additional change driver beyond the $P$ change. Figure $2 \mathrm{~b}$ shows that a notable shift occurs also in the temporal development of relative evapotranspiration $\mathrm{AET}_{\mathrm{wb}} / P$ (purple curve) after 1960.

With regard to possible landscape drivers of this $\mathrm{AET}_{\mathrm{wb}} /$ $P$ shift (which is not readily explainable solely by the observed atmospheric climate changes in $T$ and/or $P$ ), Fig. 2c also shows main changes in land-use within the SRC (see also Table S2). These occurred mostly prior to the $\mathrm{AET}_{\mathrm{wb}} / P$ shift, with the exception of a $2 \%$ increase in temperate deciduous forest area occurring from year 1950 to 1990. Figure $2 \mathrm{~d}$ further shows hydropower development in the SRC (normal hydropower production per catchment area, surface area and volume of man-made water reservoirs), with hydropower production capacity shifting from near-zero up to $84 \mathrm{MWh} \mathrm{km}^{-2}$ (Tables S2, S3) over the same time that $\mathrm{AET}_{\mathrm{wb}} / P$ shifted to its higher level (Fig. 2d).

In order to further investigate the possible co-development of $\mathrm{AET}_{\mathrm{wb}} / P$ and hydropower production (as a proxy of also other hydropower-related changes in the SRC, such as those in surface area and volume of man-made water reservoirs; Fig. 2d), we distinguish two subcatchments of the SRC that differ greatly in terms of their hydropower 

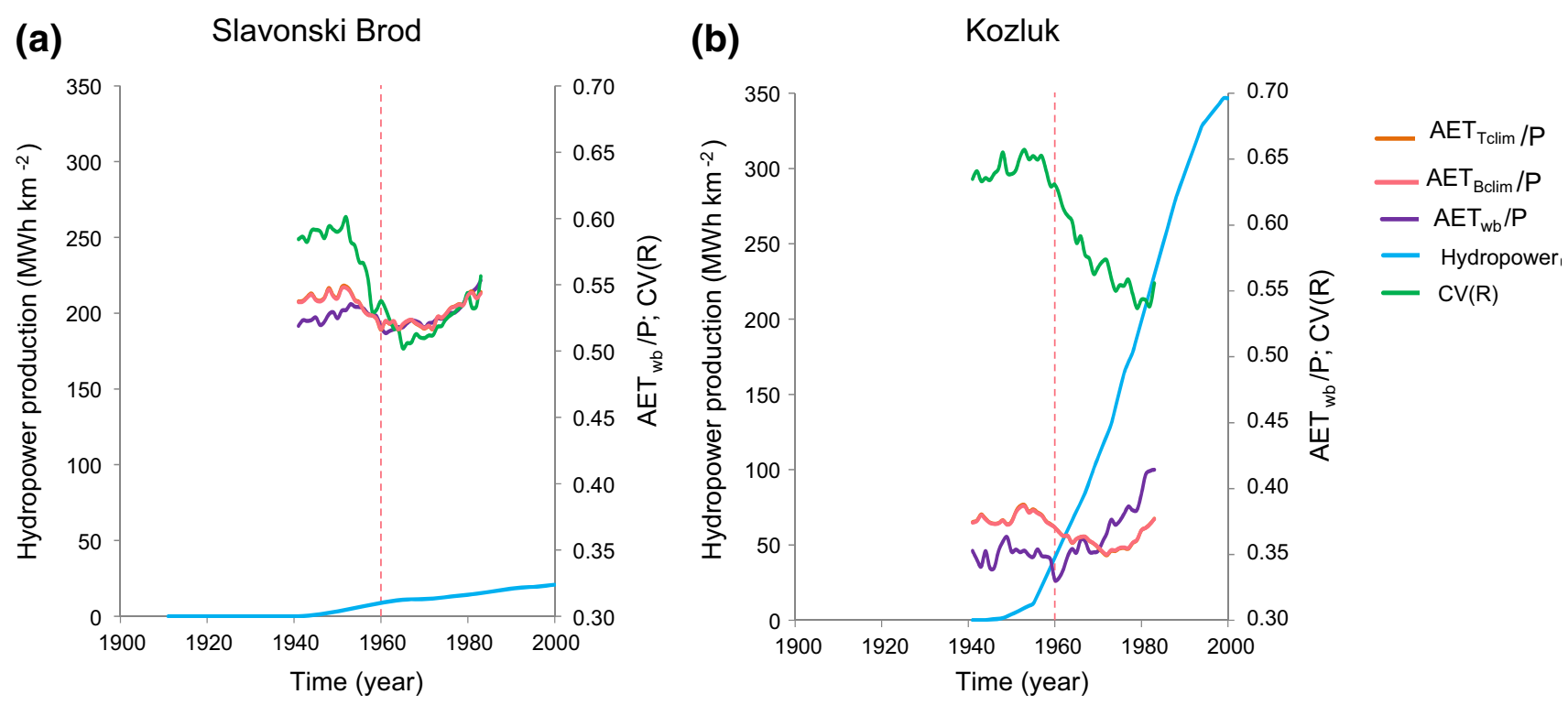

Fig. 3 Change and variable co-development over the twentieth century shown as 20-year moving averages for: relative actual evapotranspiration $\left(\mathrm{AET}_{\mathrm{wb}} / P\right)$; relative evapotranspiration climate estimates of $\mathrm{AET}_{\mathrm{Bclim}} / P$ and $\mathrm{AET}_{\mathrm{Tclim}} / P$ (where $\mathrm{AET}_{\mathrm{Bclim}}$ and $\mathrm{AET}_{\mathrm{Tclim}}$ are calculated from Turc and Budyko Eqs. (2) and (3), respectively; the $\mathrm{AET}_{\mathrm{Bclim}}$ and $\mathrm{AET}_{\mathrm{Tclim}}$ values have been scaled by the ratio of average $\mathrm{AET}_{\mathrm{wb}}$ in $1931-1993$ and corresponding average $\mathrm{AET}_{\mathrm{Bclim}}$ and $\mathrm{AET}_{\mathrm{Tclim}}$, respectively); developed annual hydropower production per unit catchment area and coefficient of variation of monthly runoff $(\mathrm{CV}(\mathrm{R}))$. a Slavonski Brod. b Kozluk

development: Slavonski Brod and Kozluk (Fig. 1). Both Slavonski Brod and Kozluk exhibit similar changes as the whole SRC with regard to increase of $T$, and decrease of $P$ and $R$ (Fig. S1, Supplementary Material). Similarly to the whole SRC, increase in $\mathrm{AET}_{\mathrm{wb}} / P$ is also evident from year 1960 in both catchments (Fig. 3), but with a 2.7 times greater change magnitude in the Kozluk catchment (shift from 0.33 to 0.41 ) than in the Slavonski Brod catchment (shift from 0.52 to 0.55 ). Increases are then also visible in the purely climate-related $\mathrm{AET}_{\mathrm{Bclim}} / P$ and $\mathrm{AET}_{\mathrm{Tclim}} / P$ estimates for the Slavonski Brod catchment (Fig. 3a), but not for the Kozluk catchment where $\mathrm{AET}_{\mathrm{Bclim}} / P$ and $\mathrm{AET}_{\mathrm{Tclim}} /$ $P$ instead decrease (Fig. 3b); scaling factors for $\mathrm{AET}_{\text {Bclim }}$ and $\mathrm{AET}_{\mathrm{Tclim}}$ are 1.35 and 1.18, respectively, for Slavonski Brod, and 0.88 and 0.77, respectively, for Kozluk.

Furthermore, no sustained change in land-use is evident (Fig. S2, Supplementary Material) in any of the two subcatchments. However, the two catchments differ considerably in terms of their developed hydropower production capacity per catchment area (Figs. 3, 4), as well as their surface area and volume of man-made water reservoirs (Fig. 4). Slavonski Brod with catchment area of
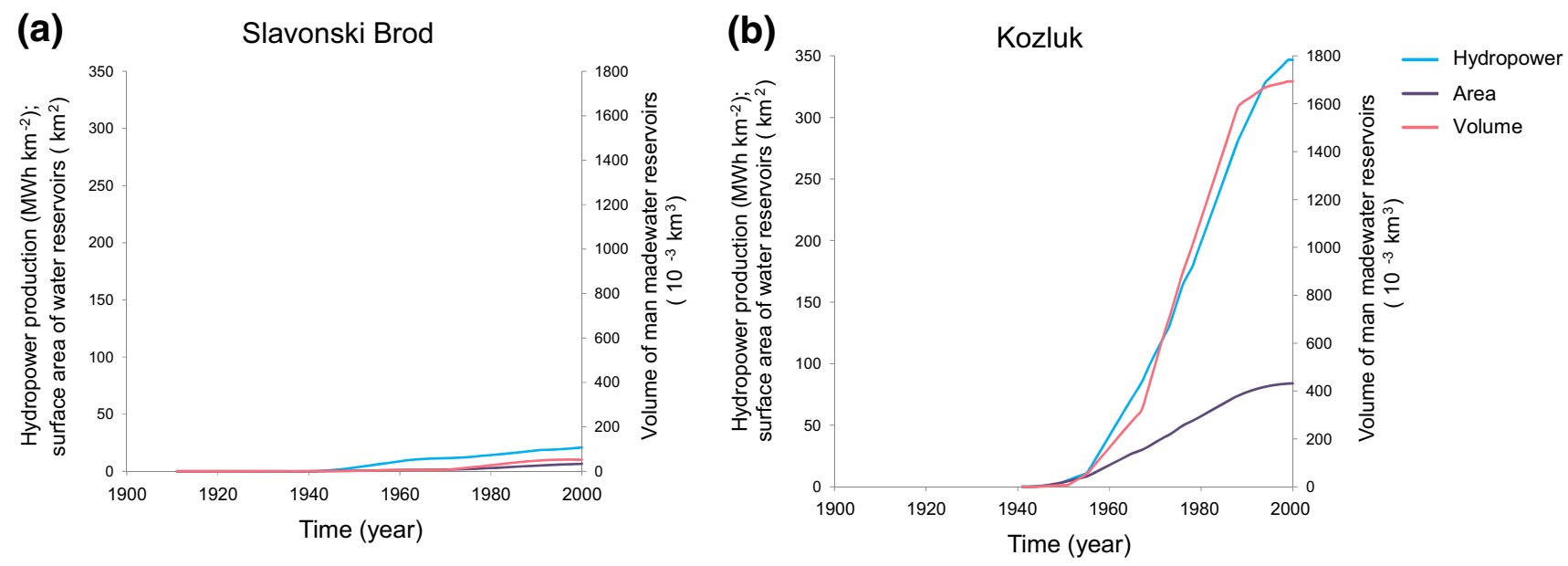

Fig. 4 Twenty-year moving averages of developed annual hydropower production per unit catchment area, water surface area and volume of man-made water reservoirs for the SRC catchments. a Slavonski Brod. b Kozluk 
$54718 \mathrm{~km}^{2}$ has developed normal annual hydropower production of $25 \mathrm{MWh} \mathrm{km}^{-2}$, while the corresponding value for Kozluk with a $17847 \mathrm{~km}^{2}$ area is $347 \mathrm{MWh} \mathrm{km}^{-2}$ (Tables S2, S3). The Kozluk catchment also exhibits a decrease in its $\operatorname{CV}(R)$ level from around the year 1960 (Fig. 3b), concurrently with the shift of $\mathrm{AET}_{\mathrm{wb}} / P$ to its higher level in this catchment. Around the same time, the Slavonski Brod catchment (Fig. 3a), after a few years of decrease, exhibits instead an increase in $\mathrm{CV}(R)$.

By the end of the year 1993, 16 times more hydropower production per catchment area (Figs. 4a, b), 13 times more water surface area of man-made reservoirs, and 50 times more water volume were developed in the Kozluk catchment than in the Slavonski Brod catchment. Figure 5a and b summarizes the changes in average T, P, R, $\mathrm{AET}_{\mathrm{wb}} / P$, $\mathrm{CV}(\mathrm{R})$, and hydropower production (HP) values from 1931-1960 to 1964-1993, with $95 \%$ confidence interval bars as obtained from the two-tailed paired Student $t$ test for the three catchments. The purely atmospheric climate changes $\Delta T$ and $\Delta P$ (Fig. 5a) are not statistically significant for any of the catchments (at 0.05 significance level). However, the decrease in runoff variability $\Delta \mathrm{CV}(R)$ is significant (at 0.05 significance level) only in the Kozluk catchment with the greatest hydropower production per catchment area. In the whole SRC with 4 times lower hydropower production per catchment area (Fig. 5b) and the Slavonski Brod catchment, with 16 times lower hydropower production per catchment area than in the Kozluk catchment, there is no significant change in $\Delta \mathrm{CV}(R)$ (Fig. 5b). For all three catchments, we also performed an ANCOVA test under 0.05 significance level in order to further check the influence of the hydropower production proxy (as an independent variable) on $\mathrm{AET}_{\mathrm{wb}} / P$ (as an outcome variable), taking into consideration $\mathrm{AET}_{\mathrm{Bclim}} / P$
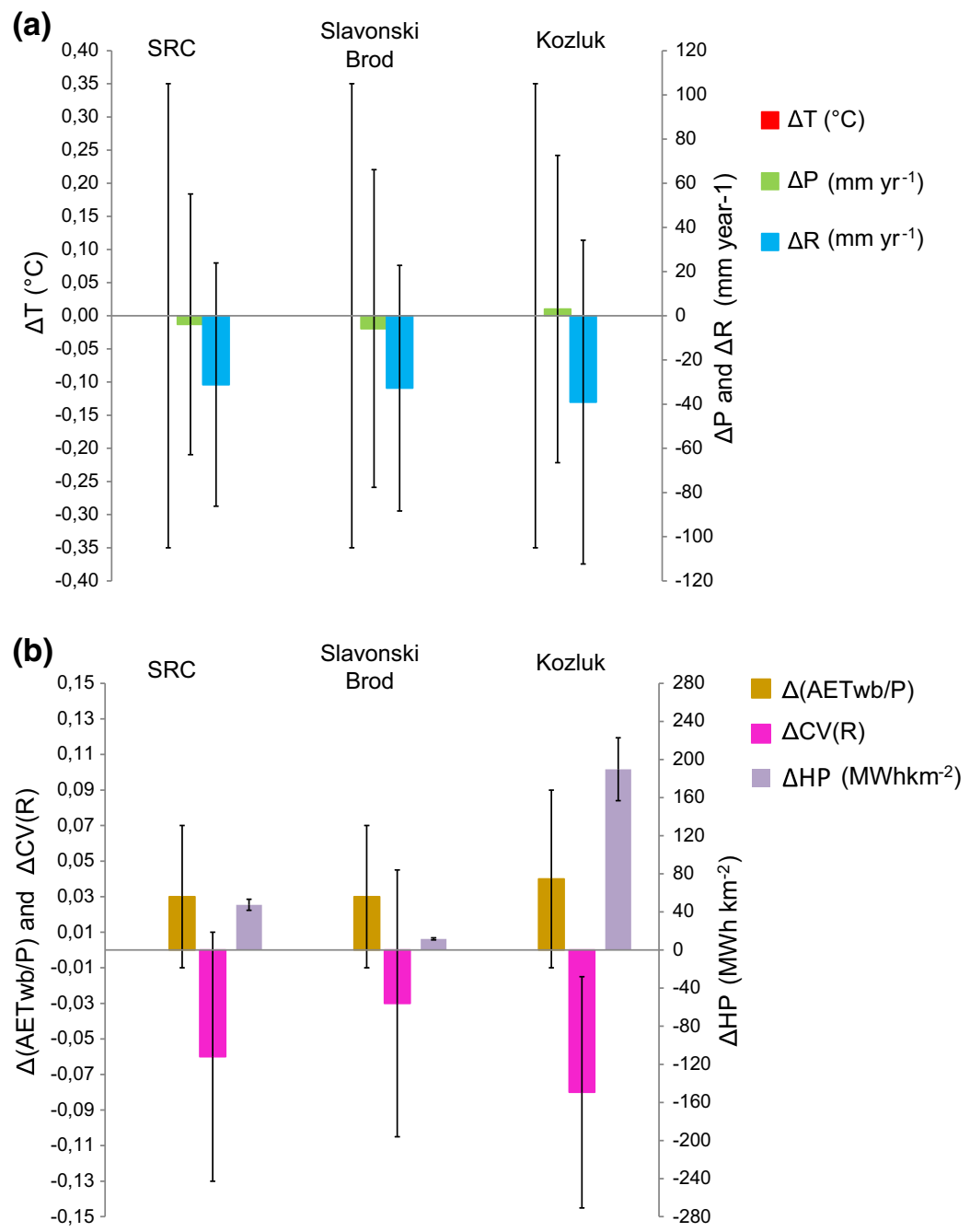

Fig. 5 Change $(\Delta)$ in hydroclimatic variables and hydropower production development in the SRC and its subcatchments. a Temperature $(T)$, precipitation $(P)$, runoff $(R)$. b Relative actual evapotranspiration $(\mathrm{AETwb} / P)$, coefficient of variation of monthly runoff $\mathrm{CV}(R)$ and developed hydropower production per catchment area (HP). Error bars show $95 \%$ confidence intervals for the hydroclimatic and hydropower changes 

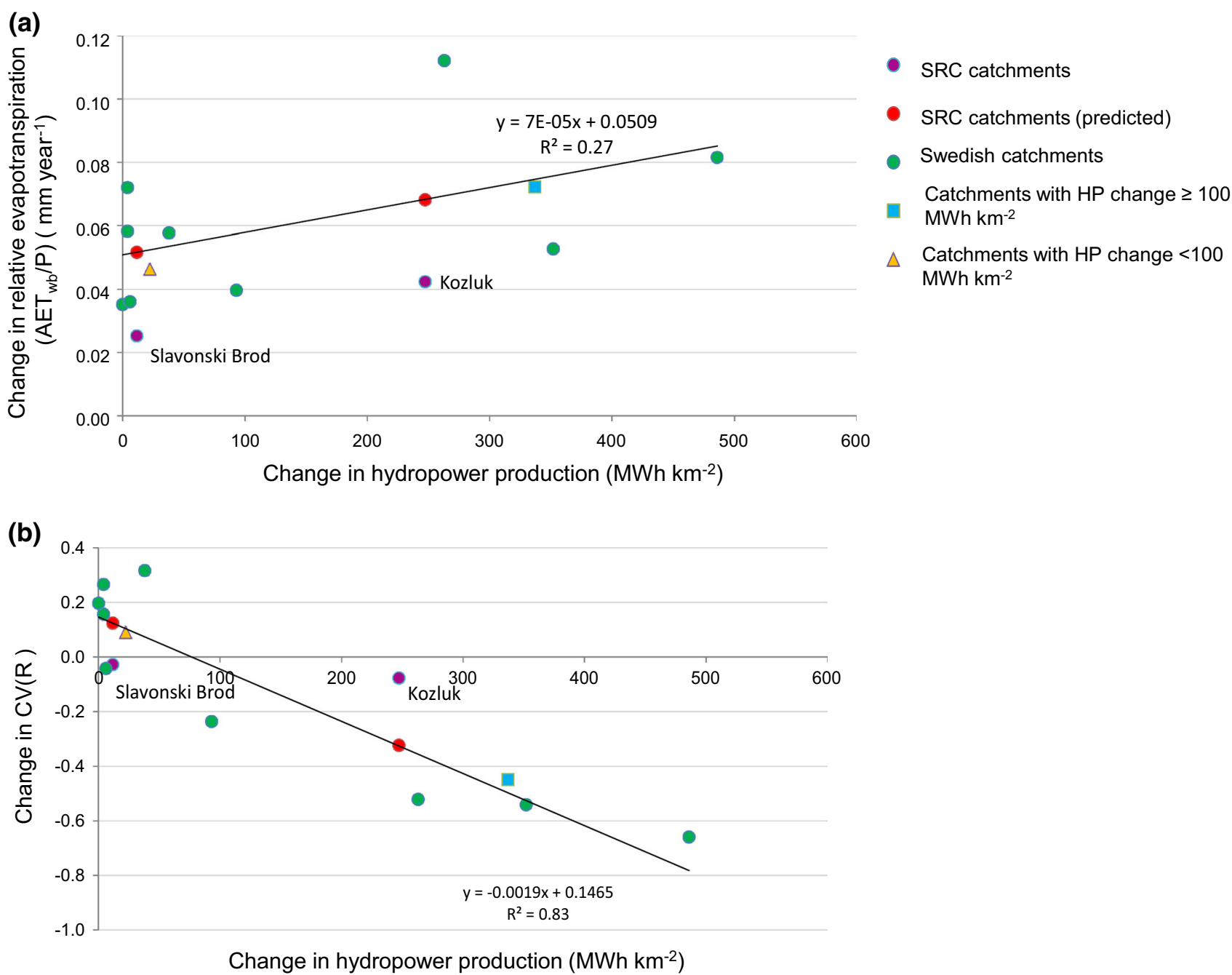

Fig. 6 Cross-regional relation between changes. a Changes in relative evapotranspiration $\left(\mathrm{AET}_{\mathrm{wb}} / P\right)$ and hydropower production between periods (1931-1960) and (1971-2000) [(1964-1993) for Slavonski Brod and Kozluk]. b Changes in coefficient of variation of runoff CV(R) and hydropower production for the same periods as in a. Results are shown for the two different SRC subcatchments (Fig. 1) (purple symbols) and compared with previously reported results (Destouni et al. 2013) for different Swedish catchments (green symbols) and predicted results for the SRC catchments (red symbols) calculated on the basis of Swedish catchments results. Regression lines are shown for the Swedish catchments' results. Illustrated are also values of average $\mathrm{AET}_{\mathrm{wb}} / \mathrm{P}$ and $\mathrm{CV}(\mathrm{R})$ change for the four catchments with hydropower production change of more than $100 \mathrm{MWh} \mathrm{km}^{-2}$ (blue square) and the seven catchments with less than $100 \mathrm{MWh} \mathrm{km}^{-2}$ (yellow rectangle)

and $\mathrm{AET}_{\mathrm{Tclim}} / P$ (as covariant variables). The test showed highly significant $(P<0.001)$ change in slope of 20 -year running average $(1940-1983)$ of $\mathrm{AET}_{\mathrm{wb}} / P$ for Kozluk catchment when taking into consideration the influence of hydropower, and no significant change when taking into consideration only climate change. No such significant results were found for Slavonski Brod and the SRC catchments. Figure 6 finally shows a direct comparison between SRC and Swedish (Destouni et al. 2013) catchment results with regard to changes in $\mathrm{AET}_{\mathrm{wb}} / P$ (Fig. 6a) and $\operatorname{CV}(R)$ (Fig. 6b) versus change in developed hydropower production per catchment area. For the Swedish catchments, there is positive correlation for $\mathrm{AET}_{\mathrm{wb}} / P$
$\left(R^{2}=0.27\right.$, Fig. 6a) and particularly so for $\mathrm{CV}(R)$ $\left(R^{2}=0.83\right.$, Fig. 6b). When including the SRC results for the two distinctly different subcatchments Slavonski Brod and Kozluk and removing local noise from the data by considering average results for catchments with hydropower production that is greater (blue square; for 4 such catchments cross-regionally) and smaller (yellow rectangle; for 7 such catchments cross-regionally) than $100 \mathrm{MWh} \mathrm{km}{ }^{-2}$, the resulting two average data points fit well to the regression lines for individual catchment data. Figure 6 also shows predicted values for the SRC catchments, calculated on the basis of the Swedish catchment results. 


\section{DISCUSSION}

The present results reveal concurrent shifts in relative evapotranspiration $\mathrm{AET}_{\mathrm{wb}} / P$ to higher level and runoff variability $\mathrm{CV}(R)$ to lower level in the SRC hydropowerdominated subcatchment of Kozluk. These $\mathrm{AET}_{\mathrm{wb}} / P$ and $\mathrm{CV}(R)$ shifts are not readily explainable by the observed concurrent climate changes in $T$ and $P$, or by any similar changes in the purely $T$ - and $P$-dependent estimates of $\mathrm{AET}_{\mathrm{Bclim}} / P$ and $\mathrm{AET}_{\mathrm{Tclim}} / P$. At the same time, the Slavonski Brod catchment, with 16 times smaller hydropower production per area than the Kozluk catchment, exhibits no significant increase in $\mathrm{CV}(R)$, while its increase in $\mathrm{AET}_{\mathrm{wb}} / P$ from 1960 is similar to such increases also in $\mathrm{AET}_{\mathrm{Bclim}} / P$ and $\mathrm{AET}_{\mathrm{Tclim}} / P$ (Fig. 3a).

In other world parts, agricultural expansion, intensification, and irrigation changes have been reported to cooccur with increases in both $\mathrm{AET}_{\mathrm{wb}} / P$ and $\operatorname{CV}(R)$ (Destouni et al. 2013; Jaramillo et al. 2013), but such changes have been small in the SRC. Hydropower production developments have also been reported to cooccur with $\mathrm{AET}_{\mathrm{wb}} / P$ increase but then along with a concurrent $\mathrm{CV}(R)$ decrease (Destouni et al. 2013), such as the changes found here for the Kozluk catchment.

The measure of hydropower production may then be a proxy for various related changes in landscape and atmospheric water. These may, for example, be changes in surrounding soil moisture, groundwater level (decreasing in areas with diverted rivers and increasing close to and downstream of reservoirs) and spatiotemporal variations of temperature (Vercauteren et al. 2013), and associated evapotranspiration (Wildi 2010) induced by the heat storage capacity of created water bodies. Large dams related to hydropower production have indeed also been shown to affect atmospheric water conditions over large distances (up to $100 \mathrm{~km}$ ) from the actual water reservoirs (Degu et al. 2011) and also snow melt has been shown to be affected by the heat storage capacity of surface water bodies (Vercauteren et al. 2014). All these and other types of water and environmental changes may thus be associated with hydropower-related building of dams, formation of reservoirs, regulation of watercourses, and river/stream/channel diversions and adjustments. Constructed water reservoirs may, further, at least occasionally, also be used for other purposes (industrial, household, flood protection, agricultural), in addition to hydropower production, which can affect regional water conditions and fluxes in various ways.

Different types of changes may thus combine in characteristic ways, quantifiable by the proxy measure of hydropower production, to yield such concurrent increase in $\mathrm{AET}_{\mathrm{wb}} / P$ and decrease in $\operatorname{CV}(R)$ as found here for the most hydropoweraffected subcatchment of Kozluk. This hydroclimatic change combination is consistent with similar changes found for comparable hydropower production conditions in Swedish catchments (Destouni et al. 2013) and more recently also in other parts of the world (Jaramillo and Destouni 2014).

\section{CONCLUSIONS}

This study has identified two different change signals on the scale of SRC subcatchments. One is related to a dominant hydropower development in the Kozluk subcatchment, which has shifted relative evapotranspiration $\mathrm{AET}_{\mathrm{wb}} / P$ to higher level and runoff variability $\mathrm{CV}(R)$ to lower level. The other signal reflects the essentially unregulated subcatchment of Slavonski Brod, with its increase of $\mathrm{AET}_{\mathrm{wb}} / P$ after 1960 being to much greater degree explainable by observed climatic change than in the Kozluk subcatchment, and its $\mathrm{CV}(R)$ fluctuating around a relatively stable value rather than shifting to some other level. The hydroclimatic change behavior in the whole reflects a combination of these two main subcatchment signals.

Methodologically, this study has shown that it may be possible to find, compile, and synthesize relevant data series for capturing and distinguishing long-term hydroclimatic change even for a complex transboundary catchment like the SRC, in a world region that has recently undergone political and social instability, with generally less accessible environmental data than in Sweden.

Hydroclimatically, the present results have quantitatively framed the recent history and present state of hydroclimate in the SRC, of relevance for water resources in several countries and for a majority of their populations. The present SRC results provide a basis for further assessment and following up of future water resource effects of projected climate and other regional changes. With regard to main drivers of hydroclimatic change, these results are more indicative than conclusive, but their implications are important for understanding water resource development in the region and more generally, and thereby worthy of further investigation and testing across catchments of various scales in different parts of the world.

Acknowledgments This work was funded by the Swedish Research Council (VR; project number 2009-3221) and carried out within the framework of the strategic research program EkoKlim at Stockholm University. We thank Prof. Ognjen Bonacci and Martina Baučić at the Faculty of Civil Engineering, Architecture and Geodesy, University of Split, Croatia, and the following institutions for providing needed data: Institute for the development of the water resources Jaroslav Černi and Meteorological and Hydrological Institute of Croatia. We thank Vladimir Cvetkovic from the Royal Institute of Technology, Stockholm, Sweden, for fruitful discussions.

Open Access This article is distributed under the terms of the Creative Commons Attribution License which permits any use, distribution, and reproduction in any medium, provided the original author(s) and the source are credited. 


\section{REFERENCES}

Asokan, S.M., and G. Destouni. 2014. Irrigation effects on hydroclimatic change: Basin-wise water balance-constrained quantification and cross-regional comparison. Surveys in Geophysics 35: 879-895. doi:10.1007/s10712-013-9223-5.

Asokan, S.M., J. Jarsjö, and G. Destouni. 2010. Vapor flux by evapotranspiration: Effects of changes in climate land use and water use. Journal Geophysical Research 115: D24102. doi:10. 1029/2010JD014417.

Botter, G., S. Basso, A. Porporato, I. Rodriguez-Iturbe, and A. Rinaldo. 2010. Natural streamflow regime alterations: Damming of the Piave river basin (Italy). Water Resources Research 46: W0652. doi:10.1029/2009WR008523.

Botter, G., S. Basso, I. Rodriguez-Iturbe, and A. Rinaldo. 2013. Resilience of river flow regimes. Proceedings of the National Academy of Sciences of the United States of America 110: 12925-12930. doi:10.1073/pnas.1311920110.

Budyko, M. I. 1974. Climate and life. New York: Academic Press, $508 \mathrm{p}$.

CCM (Catchment Characterisation and Modelling). 2008. River and Catchment Database, version 2.1 (CCM2). European Commission Institute for Environment and Ecology. Retrieved April, 2011, from http://ccm.jrc.ec.europa.eu/php/index.php?action= view\&id=23 (Last updated 1 April 2008).

Christensen, N.S., A.W. Wood, N. Voisin, D.P. Lettenmaier, and R.N. Palmer. 2004. The effects of climate change on the hydrology and water resources of the Colorado River basin. Climate Change 62: 337-363. doi:10.1023/B:CLIM.0000013684.13621.1f.

CRU (Climatic Research Unit). 2006. Retrieved April, 2011, from http://cru.csi.cgiar.org (Last updated November 2006).

Cuo, L., D.P. Lettenmaier, M. Alberti, and J.E. Richey. 2009. Effects of a century of climate and land cover change on the hydrology of the Puget Sound basin. Hydrological Processes 23: 907-933. doi:10.1002/hyp.7228.

Darracq, A., F. Greffe, F. Hannerz, G. Destouni, and V. Cvetkovic. 2005. Nutrient transport scenarios in a changing Stockholm and Mälaren valley region. Water Science and Technology 51: 31-38.

Degu, A.M., F. Hossain, D. Niyogi Sr, P. Roger Sr., J. Shepherd, M. Voisin, and T. Chronis. 2011. The influence of large dams on surrounding climate and precipitation patterns. Geophysical Reseach Letters 38: L04405. doi:10.1029/2010GL046482.

Destouni, G., S.M. Asokan, and J. Jarsjö. 2010. Inland hydro-climatic interaction: Effects of human water use on regional climate. Geophysical Research Letters 37: L18402. doi:10.1029/ 2010 GL044153.

Destouni, G., F. Jaramillo, and C. Prieto. 2013. Hydroclimatic shifts driven by human water use for food and energy production. Nature Climate Change 3: 213-217. doi:10.1038/NCLIMATE1719.

Dyurgerov, M., A. Bring, and G. Destouni. 2010. Integrated assessment of changes in freshwater inflow to the Arctic Ocean. Journal Geophysical Research 115: D12116. doi:10.1029/ 2009JD013060.

Goldewijk, K. K. 2010. ISLSCP II Historical Land Cover and Land Use, 1700-1990. In ISLSCP initiative II collection. Data set, ed. G. Hall Forest, G. Collatz, B. Meeson, S. Los, E. Brown de Colstoun, D. Landis. Available online [http://daac.ornl.gov/] from Oak Ridge National Laboratory Distributed Active Archive Center, Oak Ridge, TN. Retrieved March, 2013, from http:// daac.ornl.gov/doi:10.3334/ORNLDAAC/967.

Gordon, L.J., W. Steffen, B.F. Jönsson, C. Folke, M. Falkenmark, and A. Johannessen. 2005. Human modification of global water vapor flows from the land surface. Proceedings of the National Academy of Sciences of the United States of America 102: 7612-7617. doi:10.1073/pnas.0500208102.
Groves, D.G., D. Yates, and C. Tebaldi. 2008. Developing and applying uncertain global climate change projections for regional water management planning. Water Resources Research 44: W12413. doi:10.1029/2008WR006964.

Hamlet, A.F., and D.P. Lettenmaier. 1999. Columbia River streamflow forecasting based on ENSO and PDO climate signals. Journal of Water Resources Planning and Management 125: 333-341. doi:10.1061/(ASCE)0733-9496(1999).

Hossain, F. 2010. Empirical relationship between large dams and the alteration in extreme precipitation. Natural Hazards Review 11: 97-101. doi:10.1061/(ASCE)NH.1527-6996.0000013.

International Commision for the Protection of the Danube River (ICPDR). 2005. Danube Basin analysis: Part A-Basin-wide overview (WFD Roof Report 2004). International Commission for the Protection of the Danube River (ICPDR). ICPDR Document IC/084, 18 March 2005.

International Commision for the Protection of the Danube River (ICPDR). 2009. Flood protection expert group: Sub-basin Level Flood Action Plan, Sava River Basin. International Commision for the Protection of the Danube River (ICPDR): Vienna.

International Commision on Large Dams (ICOLD). 1997. Position Paper on Dams and the Environment. Paris: International Commision on Large Dams (ICOLD).

International Sava River Comission. 2008. Sava River Basin analysis report. Zagreb: International Sava River Comission.

Jaramillo, F., and G. Destouni. 2014. Developing water change spectra and distinguishing change drivers worldwide. Geophysical Research Letters 41: 8377-8386. doi:10.1002/ 2014 GL061848.

Jaramillo, F., C. Prieto, S.W. Lyon, and G. Destouni. 2013. Multimethod assessment of evapotranspiration shifts due to non-irrigated agricultural development in Sweden. Journal of Hydrology 484: 55-62. doi:10.1016/j.jhydrol.2013.01.010.

Jarsjö, J., Y. Shibuo, and G. Destouni. 2008. Spatial distribution of unmonitored inland water discharges to the sea. Journal of Hydrology 348: 59-72. doi:10.1016/j.jhydrol.2007.09.052.

Jarsjö, J., S.M. Asokan, C. Prieto, A. Bring, and G. Destouni. 2012. Hydrological responses to climate change conditioned by historic alterations of land-use and water-use. Hydrology and Earth System Sciences 16: 1335-1347. doi:10.5194/hess-161335-2012.

Kundzewicz, Z., L.J. Mata, N.W. Arnell, P. Döll, B. Jimeney, K. Miller, T. Oki, Z. Sen, and I. Shiklomanov. 2008. The implications of projected climate change for freshwater resources and their management. Hydrological Sciences Journal 53: 3-10.

Kvalevåg, M.M., G. Myhre, G. Bonan, and S. Levis. 2010. Anthropogenic land cover changes in a GCM with surface albedo changes based on MODIS data. International Journal of Climatology 30: 2105-2117.

Langbein, W. B. et al. 1949. Annual runoff in the United States. US Geological Survey Circular 52, Washington, DC, 14 p.

Lee, E., W.J. Sacks, T.N. Chase, and J.A. Foley. 2011. Simulated impacts of irrigation on the atmospheric circulation over Asia. Journal of Geophysics Research 116: D08114. doi:10.1029/ 2010JD014740.

Lobell, D., G. Bala, A. Mirin, T. Phillips, R. Maxwell, and D. Rotman. 2009. Regional differences in the influence of irrigation on climate. Journal of Climate 22: 2248-2255. doi:10.1175/ 2008JCLI2703.1.

Milly, P.C.D., K.A. Dunne, and A.V. Vecchia. 2005. Global pattern of trends in streamflow and water availability in a changing climate. Nature 438: 347-350. doi:10.1038/nature04312.

Mitchell, T.D., and P.D. Jones. 2005. An improved method of constructing a database of monthly climate observations and associated high-resolution grids. International Journal of Climatology 25: 693-712. doi:10.1002/joc.1181. 
Montanari, A., G. Young, H.H.G. Savenije, D. Hughes, T. Wagener, L.L. Ren, D. Koutsoyiannis, C. Cudennec, E. Toth, S. Grimaldi, G. Blöschl, M. Sivapalan, K. Beven, H. Gupta, M. Hipsey, B. Schaefli, B. Arheimer, E. Boegh, S.J. Schymanski, G. Di Baldassarre, B. Yu, P. Hubert, Y. Huang, A. Schumann, D.A. Post, V. Srinivasan, C. Harman, S. Thompson, M. Rogger, A. Viglione, H. McMillan, G. Characklis, Z. Pang, and V. Belyaev. 2013. "Panta Rhei-Everything Flows": Change in hydrology and society-The IAHS Scientific Decade 2013-2022. Hydrological Sciences Journal 58: 1256-1275. doi:10.1080/02626667. 2013.809088.

Naik, P.K., and D.A. Jay. 2011. Distinguishing human and climate influences on the Columbia River: Changes in mean flow and sediment transport. Journal of Hydrology 404: 259-277. doi:10. 1016/j.jhydrol.2011.04.035.

Nilsson, C., C.A. Reidy, M. Dynesius, and C. Revenga. 2005. Fragmentation and flow regulation of the world's large river systems. Science 308: 405-408. doi:10.1126/science.1107887.

Niyogi, D., C.M. Kishtawal, S. Tripathi, and R.S. Govindaraju. 2010. Observational evidence that agricultural intensification and land use change may be reducing the Indian summer monsoon rainfall. Water Resources Research 46: W03533. doi:10.1029/ 2008WR007082.

Poff, N.L., J.D. Olden, D.M. Merritt, and D.M. Pepin. 2007. Homogenization of regional river dynamics by dams and global biodiversity implications. Proceedings of the National Academy of Sciences of the United States of America 104: 5732-5737. doi:10.1073/pnas.0609812104.

Seneviratne, S.I., D. Lüthi, M. Litschi, and C. Schär. 2006. Landatmosphere coupling and climate change in Europe. Nature 443: 205-209. doi:10.1038/nature05095.

Shibuo, Y., J. Jarsjö, and G. Destouni. 2007. Hydrological responses to climate change and irrigation in the Aral Sea drainage basin. Geophysical Reseach Letters 34: L21406. doi:10.1029/ 2007 GL031465.

Sorooshian, S., J. Li, K. Hsu, and X. Gao. 2012. Influence of irrigation schemes used in regional climate models on evapotranspiration estimation: Results and comparative studies from California's Central Valley agricultural regions. Journal Geophysical Research 117: D06107. doi:10.1029/2011JD016978.

Turc, L. 1954. The water balance of soils-Relation between precipitation evaporation and flow. Annales Agronomiques 5: 491-569.

USGS HydroSHEDS. 2006. US. Department of Interior, US Geological Survey. Retrieved February, 2012, from http:// gisdata.usgs.gov/website/HydroSHEDS/ (Last updated January 13, 2006).

Van der Velde, Y., S.W. Lyon, and G. Destouni. 2013. Data-driven regionalization of river discharges and emergent land coverevapotranspiration relationships across Sweden. Journal of Geophysical Research 118: 2576-2587. doi:10.1002/jgrd.50224.

Van der Velde, Y., N. Vercauteren, F. Jaramillo, S.C. Dekker, G. Destouni, and S.W. Lyon. 2014. Exploring hydroclimatic change disparity via the Budyko framework. Hydrological Processes 28: 4110-4118. doi:10.1002/hyp.9949.

Vercauteren, N., G. Destouni, C.J. Dahlberg, and K. Hylander. 2013. Fine-resolved, near-coastal spatiotemporal variation of temperature in response to insolation. Journal of Applied Meteorology and Climatology 52: 1208-1220.

Vercauteren, N., S.W. Lyon, and G. Destouni. 2014. Seasonal influence of insolation on fine-resolved air temperature variation and snowmelt. Journal of Applied Meteorology and Climatology 53: 323-332.

Voros, N.G., C.T. Kiranoudis, and Z.B. Maroulis. 1999. Short-cut design of small hydroelectric plants. Renewable Energy 19: 545-563. doi:10.1016/S0960-1481(99)00083-X.
Wildi, W. 2010. Environmental hazards of dams and reservoirs. NEAR Curriculum in Natural Environmental Science, Terre et Environnement 88: 187-197.

Wisser, D., B.M. Fekete, C.J. Vörösmarty, and A.H. Schumann. 2010. Reconstructing 20th century global hydrography: A contribution to the Global Terrestrial Network-Hydrology (GTN-H). Hydrology and Earth System Sciences 14: 1-24. doi:10.5194/hess14-1-2010.

\section{AUTHOR BIOGRAPHIES}

Lea Levi $(\varangle)$ is a $\mathrm{PhD}$ student at the Department of Sustainable development, Environmental science and Engineering (SEED), Royal Institute of Technology (KTH) in Stockholm and at the Department of Applied Hydraulics, Faculty of Civil Engineering, Architecture and Geodesy, University of Split, Croatia. She is also working as a research assistant at the Department of Physical Geography at Stockholm University. She completed her MSc in Civil Engineering at Faculty of Civil Engineering, Architecture and Geodesy, University of Split, Croatia. Her thesis concerns hydroclimatic changes and their drivers within river catchments.

Address: Department of Sustainable Development, Environmental Science and Engineering (SEED), Royal Institute of Technology (KTH), Teknikringen 76, 10044 Stockholm, Sweden.

Address: Department of Physical Geography, Stockholm University, 10691 Stockholm, Sweden.

Address: Bolin Centre for Climate Research, Stockholm University, 10691 Stockholm, Sweden.

Address: Department of Applied Hydraulics, Faculty of Civil Engineering, Architecture and Geodesy, University of Split, 21000 Split, Croatia.

e-mail: 1levi@kth.se

Fernando Jaramillo is a PhD student at the Department of Physical Geography at Stockholm University. He completed his MSc in Civil Engineering at McGill University, Montreal, and his BAI at Universidad de los Andes, Bogota.

Address: Department of Physical Geography, Stockholm University, 10691 Stockholm, Sweden.

Address: Bolin Centre for Climate Research, Stockholm University, 10691 Stockholm, Sweden.

e-mail: fernando.jaramillo@natgeo.su.se

Roko Andričević is professor of Water Resources, Environmental Engineering and Stochastic Modeling at the Faculty of Civil Engineering, Architecture and Geodesy, University of Split, Croatia. He is Deputy Minister of Science, Education and Sports in Croatian Government.

Address: Department of Applied Hydraulics, Faculty of Civil Engineering, Architecture and Geodesy, University of Split, 21000 Split, Croatia.

e-mail: rokoand@gradst.hr

Georgia Destouni is professor of Hydrology, Hydrogeology and Water Resources at Stockholm University. She is member of the Royal Swedish Academy of Sciences, member of the Royal Swedish Academy of Engineering Sciences, and Secretary General of the Swedish Research Council Formas.

Address: Department of Physical Geography, Stockholm University, 10691 Stockholm, Sweden.

Address: Bolin Centre for Climate Research, Stockholm University, 10691 Stockholm, Sweden.

e-mail: georgia.destouni@natgeo.su.se 